\title{
Pendekatan Service Oriented Architecture (SOA) Pada Pelaksanaan E-Government di Kementerian Hukum dan HAM RI
}

\author{
Juli SaptaPutra Hantana \\ Magister Teknik Elektro \\ Program Pasca Sarjana Universitas Udayana \\ Denpasar, Indonesia \\ juli_sapta@hotmail.com
}

\begin{abstract}
Abstrak - Dalam konteks perkembangan teknologi informasi dan komunikasi secara umum, proyek pengembangan egovernment telah menjadi bagian dari kebijakan nasional di seluruh dunia. Tujuan dari e-government adalah untuk memberikan kesempatan kepada masyarakat dan sektor swasta untuk mengakses layanan pemerintah melalui pemberian layanan yang terintegrasi, efektif dan efisien di mana saja, kapan saja dan dalam bentuk yang nyaman melalui penggunaan internet dan saluran lain seperti ponsel, dll, selain itu juga memberikan kesempayan pada masyarakat untuk mengambil bagian dalam penyusunan kebijakan pemerintah serta pengambilan keputusan. Dan berdasarkan analisa yang telah dilakukan sebelumnya, didapat indikasi adanya kebutuhan untuk mendesain ulang proses dasar pada e-government dan penggunaan Service Oriented Architecture (SOA) serta web service untuk mengoptimalkan kemampuan dari aplikasi e-government. Penggunaan Service Oriented Archictecure (SOA) memiliki peranan penting dalam mengintegrasikan departemen-departemen yang berbeda termasuk layanan dan aturannya, yang diharapkan dapat mengatasi tantangan utama dalam pengembangan e-government yaitu dalam mengintegrasikan beberapa sistem informasi publik yang bersifat heterogen beserta proses bisnis dari masing-masing organisasi dalam pemerintahan tersebut secara efisien dengan menyediakan sebuah lingkungan terpadu. Pengembangan egovernment juga telah dilaksanakan di Indonesia sesuai dengan amanat Inpres No. 3/2003. Akan tetapi kondisi penerapannya di lapangan sangat bervariasi, ada instansi pemerintah yang sudah cukup maju, tetapi banyak juga yang masih dalam taraf mendengar dan mengenalnya. Kementerian Hukum dan Hak Asasi Manusia sebagai salah instansi pemerintah yang memiliki tugas fungsi yang cukup beragam dalam rangka pelayanan publik, telah melakukan inisiatif pengembangan e-government seperti tercantum dalam rencana strategis yang telah ditetapkan untuk periode 2010 2014. Seperti halnya tantangan yang dihadapi dalam pengembangan e-government secara umum, dengan kondisi satuan kerja dan unit pusat dari Kementerian Hukum dan HAM yang memiliki tugas dan fungsi yang beragam menuntut sebuah Arsitekur Sistem Informasi Manajemen yang efisien yang dapat mengintegrasikan berbagai aplikasi dan proses bisnis dalam
\end{abstract}

lingkungan yang terpadu. Dalam paper ini penulis akan membahas pendekatan Service Oriented Architecture (SOA) dalam Arsitektur Sistem Informasi Manajemen pada Kementerian Hukum dan HAM.

Kata Kunci - E-Government; Service Oriented Architecture (SOA); Sistem Informasi Manajemen; Kementerian Hukum dan HAM.

\section{PENDAHULUAN}

Dalam konteks perkembangan teknologi informasi dan komunikasi secara umum, proyek pengembangan egovernment telah menjadi bagian dari kebijakan nasional di seluruh dunia, dan secara global proyek e-government masih terbatas dalam memberikan layanan publik secara digital yang difokuskan pada optimalisasi transaksi, meningkatkan transparansi dan memperluas pelayanan secara on-line [1]. Egovernment sendiri merupakan penggunaan teknologi informasi dan komunikasi modern seperti internet, local area network, wide area network, teknologi mobile, dan sebagainya, oleh pemerintah untuk meningkatkan efektifitas, efisiensi dan pemberian layanan kepada penduduk untuk meningkatkan transparansi [2]. E-Government dapat diaplikasikan pada legislatif, yudikatif, atau administrasi publik, untuk meningkatkan efisiensi internal, menyampaikan pelayanan publik, atau proses kepemerintahan yang demokratis. Model penyampaian yang utama adalah Government-to-Citizen atau Government-to-Customer (G2C), Government-to-Business (G2B) serta Government-to-Government (G2G).

Implementasi e-government memiliki beberapa tujuan dan sasaran yang sesuai dengan prinsip-prinsip antara lain :

1. Peningkatan pemberian layanan pemerintah

2. Pemberdayaan masyarakat melalui akses yang lebih besar untuk mendapatkan informasi dari pemerintah dan kemampuan untuk dapat berinteraksi dan berpartisipasi 
3. Keberhasilan dalam transparansi dan akuntabilitas yang lebih tinggi dari pemerintah

4. Peningkatan hubungan internal antara pemerintah dan pengiriman elektronik warga

Berdasarkan prinsip-prinsip tersebut, maka tujuan dari egovernment adalah untuk memberikan kesempatan kepada masyarakat dan sektor swasta untuk mengakses layanan pemerintah melalui pemberian layanan yang terintegrasi, efektif dan efisien di mana saja, kapan saja dan dalam bentuk yang nyaman melalui penggunaan internet dan saluran lain seperti ponsel, dll, selain itu juga memberikan kesempayan pada masyarakat untuk mengambil bagian dalam penyusunan kebijakan pemerintah serta pengambilan keputusan [3].

Salah satu tantangan utama dalam pengembangan egovernment adalah mengintegrasikan beberapa sistem informasi publik yang bersifat heterogen beserta proses bisnis dari masing-masing organisasi dalam pemerintahan tersebut secara efisien dengan menyediakan sebuah lingkungan terpadu [4]. Dan berdasarkan analisa yang telah dilakukan sebelumnya, didapat indikasi adanya kebutuhan untuk mendesain ulang proses dasar pada e-government dan penggunaan Service Oriented Architecture (SOA) serta web service untuk mengoptimalkan kemampuan dari aplikasi e-government, penggunaan Service Oriented Archictecure (SOA) memiliki peranan penting dalam mengintegrasikan departemendepartemen yang berbeda termasuk layanan dan aturannya [3].

Studi mengenai pendekatan SOA dalam e-government beserta implementasinya telah dilakukan di Jordania dan Tunisia yang berdasarkan hasil studi tersebut telah menghasilkan rancangan arsitektur berbasis SOA seperti yang akan dijelaskan lebih lanjut pada Bab III. Untuk di Indonesia sendiri, e-government merupakan program yang inisiatifnya sudah dimulai sejak tahun 2003 seiring dengan diterbitkannya Instruksi Presiden No. 3/2003. Akan tetapi kondisi penerapannya di lapangan sangat bervariasi, ada instansi pemerintah yang sudah cukup maju, tetapi banyak juga yang masih dalam taraf mendengar dan mengenalnya. Kementerian Hukum dan Hak Asasi Manusia sebagai salah instansi pemerintah yang memiliki tugas fungsi yang cukup beragam dalam rangka pelayanan publik, telah melakukan inisiatif pengembangan e-government seperti tercantum dalam rencana strategis yang telah ditetapkan untuk periode 2010-2014. Dan dalam kerangka pelaksanaan e-government di lingkungan Kementerian Hukum dan HAM tersebut telah dikembangkan sebuah Sistem Informasi Manajemen untuk mendukung pelaksanaan tugas koordinasi serta pemberian dukungan administrasi di lingkungan Kementerian Hukum dan Hak Asasi Manusia.

Seperti halnya tantangan yang dihadapi dalam pengembangan e-government secara umum, dengan kondisi satuan kerja dan unit pusat yang memiliki tugas dan fungsi yang beragam menuntut sebuah Arsitekur Sistem Informasi Manajemen yang efisien yang dapat mengintegrasikan berbagai aplikasi dan proses bisnis dalam lingkungan yang terpadu. Dalam paper ini penulis akan membahas pendekatan Service Oriented Architecture (SOA) dalam Arsitektur Sistem Informasi Manajemen pada Kementerian Hukum dan HAM.

\section{SERVICE ORIENTED ARCHITECTURE}

Service Oriented Architecture (SOA) dapat didefinisikan sebagai sebuah pendekatan arsitektur yang menggunakan service sebagai konstruksi dasar untuk mendukung pengembangan yang cepat dengan biaya yang rendah dan memiliki kemudahan dalam mengatur komposisi aplikasi yang terdistribusi dalam lingkungan yang heterogen sekalipun [5]. Service Oriented Architecture merupakan sebuah solusi untuk menyelesaikan permasalahan dalam pengembangan egovernment dimana layanan e-government memerlukan tingkat interoperabilitas dan distribusi yang tinggi mengingat banyaknya entitas yang ditangani. Dalam menggunakan pendekatan SOA, semua komponen aplikasi dimodelkan sebagai service. Terdapat tiga actor yang terlibat dalam Service Oriented Architecture [6] seperti terlihat pada Gambar No 1 dibawah ini :

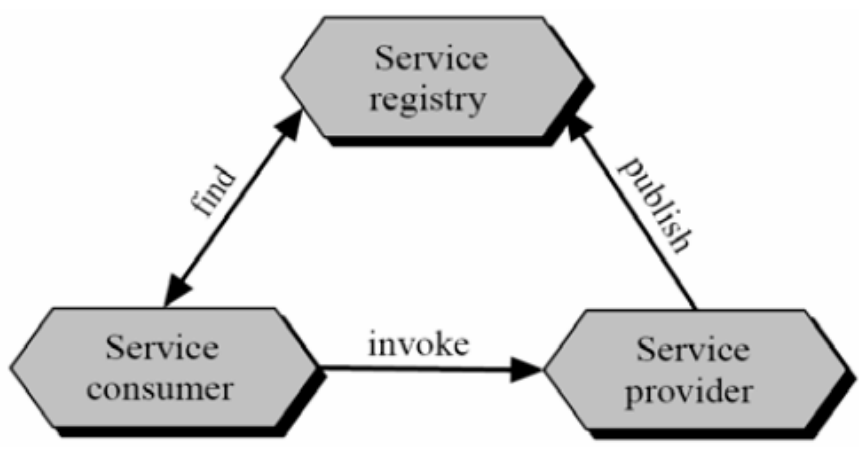

Gambar 1. Model desain dari sebuah Service Oriented Architecture

- Service Provider; merupakan entitas yang menciptakan sebuah service dan membuatnya dapat digunakan oleh entitas yang lain.

- Service Consumer; merupakan sebuah entitas atau sesorang yang menggunakan service yang diciptakan oleh service provider

- Service Registry; merupakan sebuah direktori terpusat dimana service provider dapat mempublish service yang telah diciptakan, dan tempat dimana service consumer dapat menemukan service yang dibutuhkan

Service Oriented Architecture (SOA) merupakan sebuah pendekatan untuk memecahkan permasalahan yang besar dan memecahnya menjadi sekumpulan kecil service untuk meyelesaikan permasalahan yang lebih spesifik. SOA tidak terikat pada sebuah teknologi, tetapi lebih menekankan pada 


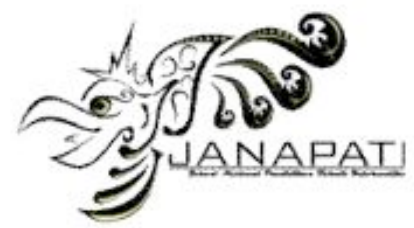

pendekatan untuk membangun sebuah sistem yang modular. Selain tiga aktor yang terlibat dalam model desain SOA, SOA juga terdiri dari empat komponen, antara lain :

- Message, berupa data yang dibutuhkan untuk menyelesaikan sebuah pekerjaan yang dipertukarkan antara satu service dengan service yang lain

- Operation, berupa fungsi yang dimiliki oleh service untuk memproses dan menghasilkan sesuatu. Fungsi ini akan berinteraksi dengan fungsi lainnya untuk menyelesaikan sebuah pekerjaan.

- Service, merepresentasikan sekumpulan operasi yang saling berkaitan utuk menyelesaikan sebuah pekerjaan

- Process, merupakan business rule yang menentukan operasi mana yang akan digunakan untuk mencapai tujuan tertentu.

Dalam implementasi Service Oriented Architecture, salah satu teknologi yang paling sering digunakan adalah Web Service. Teknologi ini memberikan standar untuk pertukaran pesan dan deskripsi dari service itu sendiri. Web Service didefinisikan oleh W3C sebagai sebuah sistem perangkat lunak yang didesain untuk mendukung interoperabilitas antar perangkat dalam sebuah jaringan. Sebuah Web Service memiliki beberapa standar yang dibutuhkan dalam mengimplementasikan Service Oriented Architecture [6], antara lain :

- Simple Object Access Protocol (SOAP), mendefinisikan struktur dari pesan dan protocol yang digunakan untuk standar dalam pertukaran informasi di jaringan yang heterogen. Dapat digunakan sebagai protokol pertukaran pesan dalam SOA.

- Web Service Description Language (WSDL), sebuah bahasa yang digunakan oleh service provider untuk menggambarkan service yang diciptakannya dalam konteks interoperabilitas. Dengan menggunakan SOAP dan WSDL, operasi "invoke" pada model desain SOA (seperti yang ditunjukkan pada Gambar No. 1) dapat dilakukan.

- Universal Description, Discovery and Integration (UDDI) sebagai pilihan teknologi untuk mengimplementasikan service broker. Digunakan untuk mengimplementasikan operasi "publish" dan "invoke" pada model desain SOA (seperti yang ditunjukkan pada Gambar No. 1).

Hubungan dari standar-standar Web Service tersebut dapat dilihat pada gambar No. 2 dibawah ini :

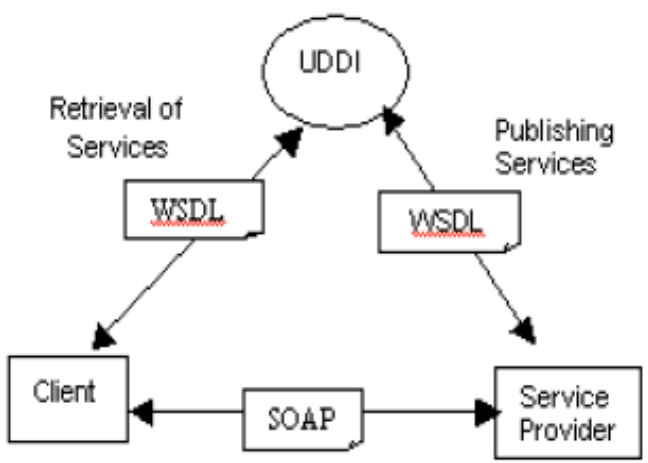

Gambar 2. Standar Web Service dan Keterkaitannya [4]

\section{SOA PADA E-GOVERNMENT}

Tujuan utama dari e-government adalah untuk menyediakan informasi yang dibutuhkan oleh masyarakat dalam rangka meningkatkan efisiensi dan kualitas layanannya. Dan pendekatan SOA pada e-government menyelaraskan Teknologi Informasi dengan tujuan pemberian layanan dan memungkinkan departemen-departemen yang berbeda untuk menggunakan kembali sumber daya yang telah dikembangkan.

Dengan demikian SOA pada e-government bertujuan untuk menyediakan solusi SOA yang fleksibel untuk mengatur, mengintegrasikan, menyebarkan, mengamankan, dan menjalankan layanan, terlepas dari platform di mana mereka diciptakan [3]. Pendekatan SOA pada e-government telah diimplementasikan di beberapa negara baik negara berkembang maupun negara maju. Solusi berbasis SOA dapat mengurangi ketergantungan pada aplikasi back-end dan mengurangi kebutuhan untuk menulis kode setiap kali terjadi perubahan dalam kebijakan, solusi ini juga mengenalkan sebuah perangkat lunak baru yang mendorong kolaborasi langsung antara masyarakat dengan organisasi di dalam pemerintahan terlepas dari model penyampaiannya [2].

Menurut Zakaria I. Saleh, Rand A. Obeidat dan Yaser Khamayseh [4] yang mengusulkan sebuah arsitektur untuk egovernment di Jordania yang berbasis SOA, dalam pandangan terhadap kebutuhan baik secara umum maupun spesifik mereka memisahkan antar muka dengan aplikasi dari e-government dan membaginya menjadi 4 (empat) lapisan atau layer yaitu Client Layer, Presentation Layer, Application Layer dan Data Layer. Arsitektur yang diusulkan juga didukung oleh secured government network yang menyediakan konektivitas ke entitas pemerintahan, komunikasi antar aplikasi dan file sharing atau pertukaran antar entitas pemerintah yang pada akhirnya seluruh arsitektur tersebut akan menuju pada e-government.

Client Layer merepresentasikan berbagai channel akses ke aplikasi e-government seperti PC, mobile, PDA atau selular, 


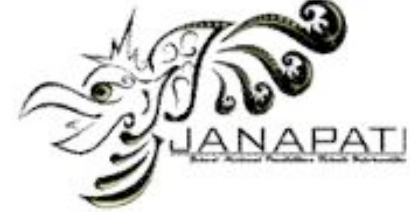

dan kiosk yang memiliki akses ke portal e-government melalui antarmuka aplikasi. Presentation Layer mengelola antarmuka untuk berinteraksi antara pengguna dengan aplikasi egovernment. Dengan memisahkan antara Presentation Layer dengan Application Layer membuat aplikasi dapat diakses dari berbagai channel seperti web browser dan dari telepon seluler sekalipun tanpa harus mengubah implementasi dari aplikasi. Adapun komunikasi antara Presentation Layer dengan Application Layer dilakukan dengan protokol SOAP melalui HTTP. Data Layer memastikan penyimpanan yang memadai bagi data-data adminisrasi pemerintahan. Manajemen untuk mengelola hak akses ke daa dilakukan oleh Database Management System (DBMS), dan layer ini juga harus dilindungi dari gangguan pihak luar dengan menggunakan firewall. Arsitektur yang diusulkan untuk e-government di Jordania dapat dilihat pada Gambar No. 3 dibawah ini :

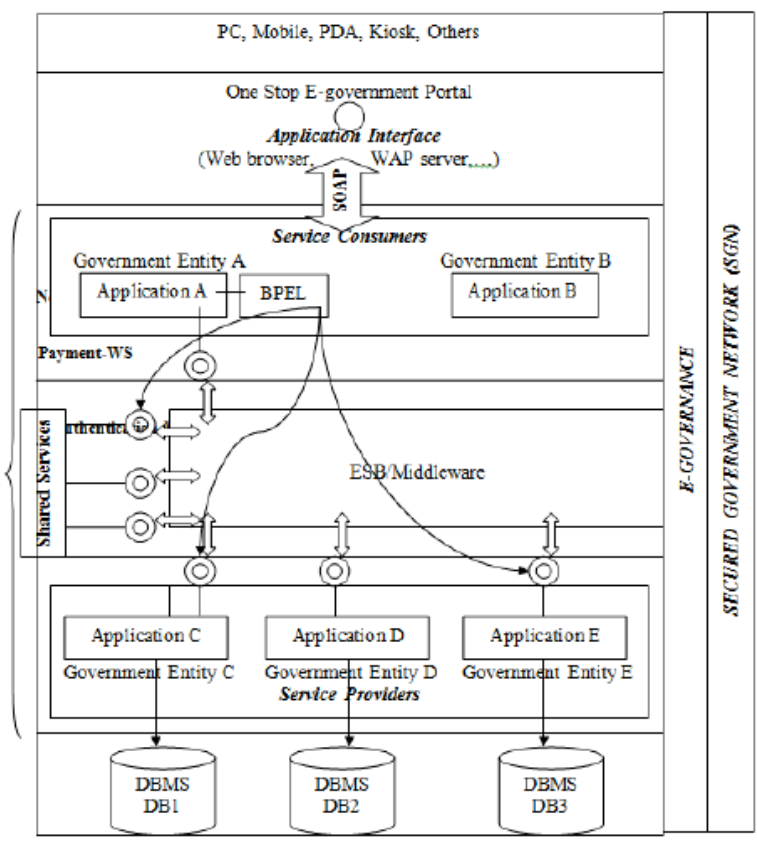

Gambar 3. Usulan Arsitektur e-government berbasis SOA [4]

Penelitian tentang implementasi SOA pada e-government juga dilakukan oleh Mohamed Sellami dan Mohamed Jmaiel dengan studi kasus di Tunisia [6]. Arsitektur yang diusulkan untuk e-government di Tunisia didapatkan melalui studi tentang kebutuhan dasar dari aplikasi e-government yang sesuai dengan kasus di Tunisia, kebutuhan tersebut utamanya mencakup keamanan yang dibagi menjadi dua kelompok yaitu yang berhubungan dengan masyarakat dan yang berhubungan dengan administrasi. Dan berdasarkan kebutuhan tersebut, mereka mengembangkan arsitektur untuk aplikasi egovernment di Tunisia seperti pada Gambar No. 4 dibawah ini

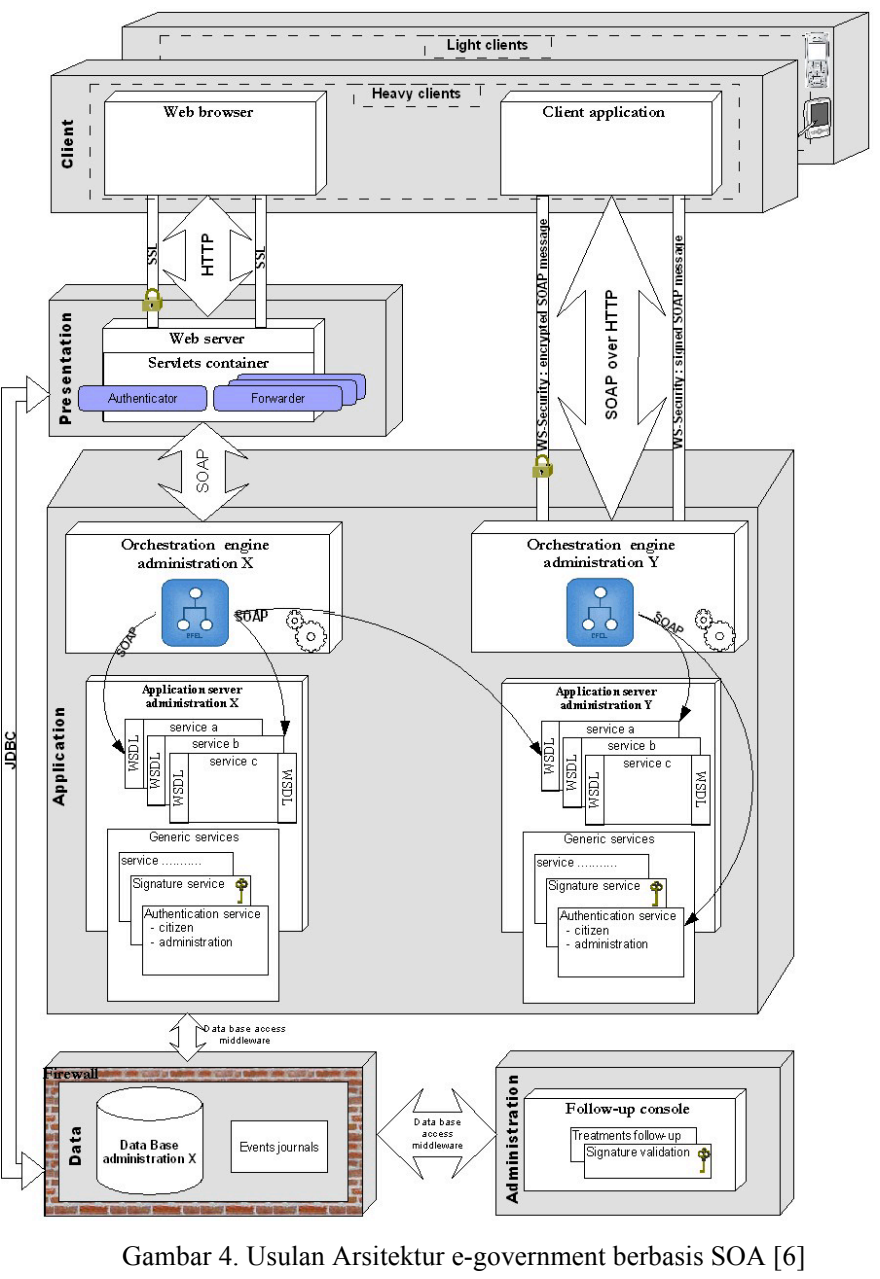

Arsitektur pada gambar diatas memiliki kemiripan dengan arsitektur yang diusulkan untuk e-government di Jordania. Namun pada arsitektur yang diusulkan untuk e-government di Tunisia lebih detail karena mengambil contoh untuk aplikasi web sesuai dengan infrastruktur teknologi di Tunisia. Selain itu terdapat tambahan satu buah lapisan atau layer yaitu Administration Layer yang hanya dapat diakses oleh atasan pegawai di administrasi pemerintahan. Layer ini memastikan adanya tindak lanjut dari layanan yang diminta oleh masyarakat atau administrasi lainnya.

\section{PENDEKATAN SOA PADA PELAKSANAAN} E-GOVERNMENT DI KEMENTERIAN HUKUM DAN HAM

Pengembangan e-government juga telah dilaksanakan di Indonesia sesuai dengan amanat Inpres No. 3/2003. Akan 


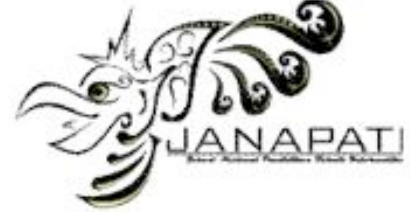

tetapi kondisi penerapannya di lapangan sangat bervariasi, ada instansi pemerintah yang sudah cukup maju, tetapi banyak juga yang masih dalam taraf mendengar dan mengenalnya. Kementerian Hukum dan Hak Asasi Manusia sebagai salah instansi pemerintah yang memiliki tugas fungsi yang cukup beragam dalam rangka pelayanan publik, telah melakukan inisiatif pengembangan e-government seperti tercantum dalam rencana strategis yang telah ditetapkan untuk periode 20102014. Dalam rencana strategis tersebut Kementerian Hukum dan HAM dalam rangka pengelolaan Teknologi Informasi dan Komunikasi memiliki Visi untuk meningkatkan pemanfaatan TIK melalui pengembangan dan pendayagunaan aplikasi telematika dalam rangka meningkatkan kualitas kehidupan berbangsa dan bernegara [7].

Untuk mewujudkan visi tersebut, Kementerian Hukum dan HAM melalui Sekretariat Jenderal di Unit Pusat telah membangun pengelolaan dukungan layanan Teknologi Informasi (TI) melalui penyusunan Rencana Induk Pengembangan Sistem Informasi Manajemen Kementerian Hukum dan Hak Asasi Manusia (SIMDK) tahun 2005-2010. Pengembangan SIMDK tersebut merupakan kerangka dasar pelaksanaan e-government di lingkungan Kemeterian Hukum dan Hak Asasi Manusia. Seperti terlihat pada Gambar No. 5 dibawah ini.

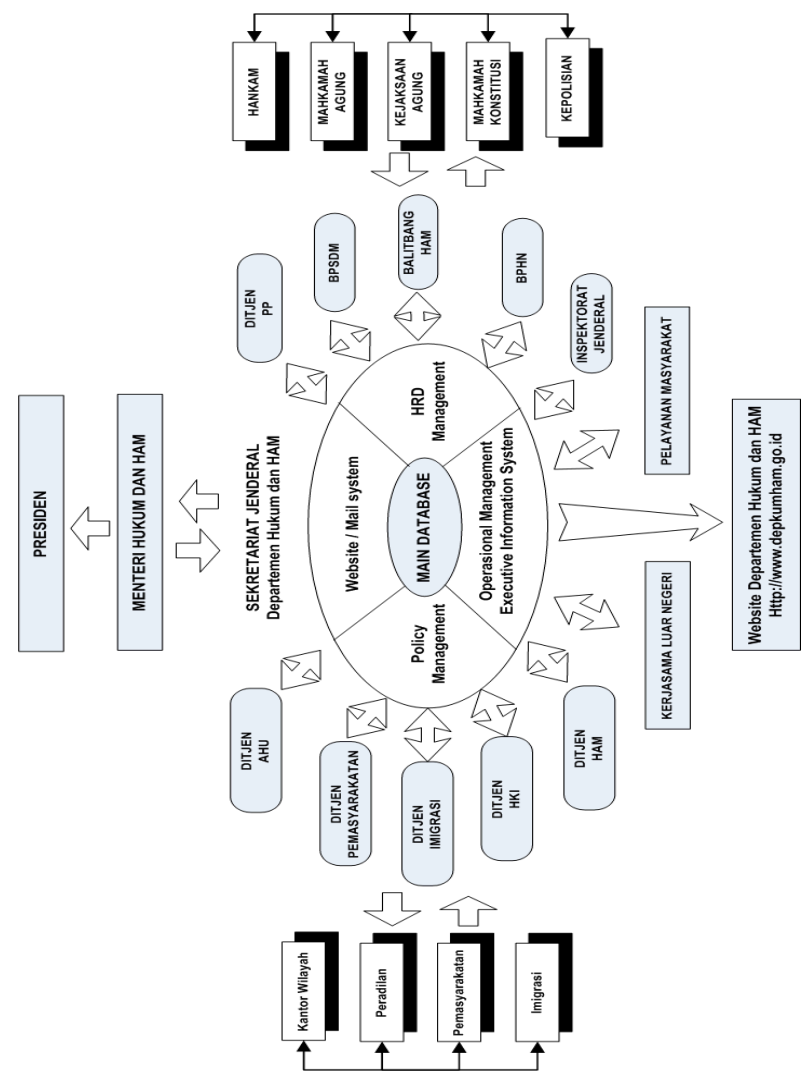

Gambar 5. Rencana Pengembangan SIMDK / SIMKUMHAM 2005-2010

Berdasarkan Rencana Pengembangan tersebut, dihasilkan Rancangan Arsitektur Sistem Informasi Manajemen Sekretariat Jenderal Kementerian Hukum dan HAM berbasis SOA yang mengintegrasikan seluruh komponen infrastruktur jaringan dan perangkat keras serta aplikasi yang berjalan diatasnya yang pada akhirnya akan menghasilkan prosesproses bisnis terotomasi yang dimanfaatkan oleh staf dan pimpinan untuk menunjang pelaksanaan tugas dan fungsi organisasi serta menjadi dasar terhadap komponen-komponen yang dibangun dalam pengembangan TI secara menyeluruh di Kementerian Hukum dan HAM.

Secara umum konsep arsitektur Sistem Informasi Manajemen Sekretariat Jenderal Kementerian Hukum dan HAM yang berbasis SOA digolongkan kedalam 4 (empat) bagian yaitu :
1.Aplikasi
2.Infrastruktur
3. Aliran Data dan Informasi
4.Kelembagaan

Keempat bagian tersebut akan tercakup dalam rancangan Arsitektur seperti terlihat pada Gambar No. 6 yang terdiri dari layanan-layanan seperti berikut :

1.Layanan Pemantauan, Optimasi dan Inovasi Bisnis

2.Layanan Pengembangan Sistem Informasi dan Infrastruktur

3.Layanan Aplikasi Bisnis

4.Layanan Otomasi, Interaksi dan Kolaborasi Proses Bisnis

5.Layanan Jembatan Antar (Enterprise Service Bus)

6.Layanan Sistem Manajemen Tata Kelola TI

7.Layanan Akses Data dan Informasi

8.Layanan Aplikasi Bisnis Eksternal

9.Layanan Infrastruktur

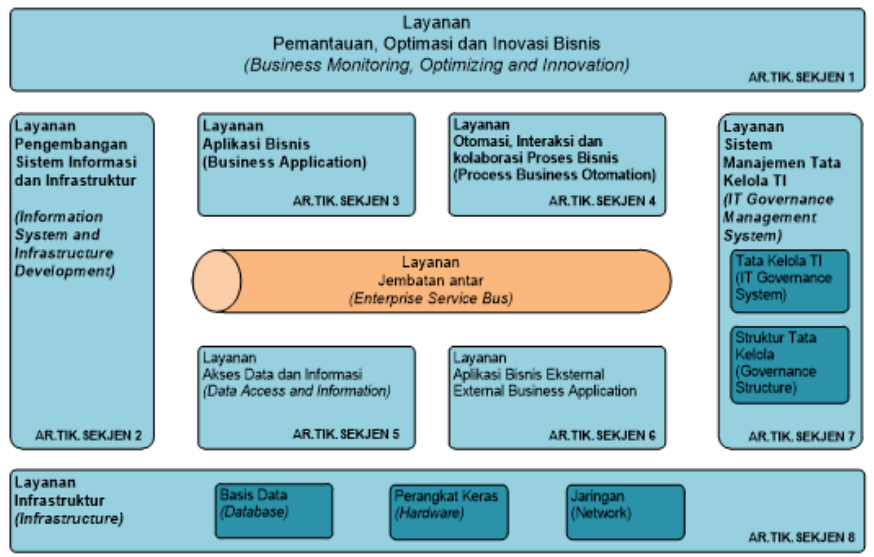

Gambar 6. Rancangan Arsitektur Sistem Informasi Manajemen Sekretariat Jenderal Kementerian Hukum dan HAM berbasis SOA [8] 
Layanan-layanan yang digambarkan pada arsitektur diatas merupakan layanan yang berdiri sendiri namun saling berkaitan satu dengan yang lainnya yang akan dimodelkan menjadi service-service yang merupakan konsep dasar dari Service Oriented Arcitecture [3]. Salah satu layanan yaitu layanan Otomasi, Interaksi dan Kolaborasi Proses Bisnis atau Business Process Management (BPM) adalah infrastruktur bisnis dari SOA yang merupakan seperangkat metode-metode, perangkat-perangkat, dan teknologi yang digunakan untuk merancang, menjalankan, menganalisa, dan mengontrol proses-proses bisnis operasional di Sekretariat Jenderal. BPM merupakan pendekatan berbasis proses yang menyeluruh untuk meningkatkan kinerja yang mengintegrasikan teknologiteknologi informasi dengan metodologi-metodologi proses. Komponen utama dalam BPM adalah workflow yang berfungsi untuk melakukan orkestrasi dan koreografi dari service-service yang ada di Sekretariat Jenderal yang telah diimplementasikan pada rancangan arsitektur Sistem Informasi Manajemen Sekretariat Jenderal Kementerian Hukum dan HAM. Setiap service akan saling berkomunikasi menggunakan perantara layanan jembatan antar (Enteprise Service Bus/ESB) dan didalam arsitektur Sistem Informasi Manajemen Sekretariat Jenderal Kementerian Hukum dan HAM berbasis infrastruktur SOA, BPM memainkan peran sentral dalam mengintegrasikan proses-proses bisnis yang terkandung didalam organisasi Sekretariat Jenderal tersebut.

Layanan Jembatan Antar atau Enterprise Service Bus (ESB) adalah tahapan final dalam mengimplementasikan SOA. ESB mengintegrasikan layanan-layanan pada rancangan Arsitektur Sistem Informasi Manajemen Sekretariat Jenderal Kementerian Hukum dan HAM. Dalam arsitektur Sistem Informasi Manajemen Sekretariat Jenderal Kementerian Hukum dan HAM yang memanfaatkan ESB, suatu service / layanan TIK akan berkomunikasi melalui bus, yang bertindak sebagai penghubung (message broker) diantara serviceservice. Keunggulan utama dari pendekatan tersebut adalah mengurangi jumlah koneksi point-to-point yang dibutuhkan oleh service-service untuk berkomunikasi yang pada akhirnya membawa implikasi terhadap pengembangan aplikasi yang besar dapat menjadi lebih mudah dan cepat. Arsitektur dari suatu ESB terpusatkan pada sebuah bus yang memberikan layanan-layanan penyampaian pesan berdasarkan standarsandar seperti SOAP dan HTTP, yang dirancang untuk tingkat keluaran yang tinggi, penyampaian pesan yang terjamin pada beragam pemberi dan penerima service. ESB mendorong service-service untuk berinteraksi satu sama lain berdasarkan kebutuhan kualitas service dari masing-masing transaksi. ESB juga mendorong beragam standar seperti SOAP, XML, WSDL, JMS, J2EE, JAX-RPC, dan lain-lain.
Terdapat beberapa tipe komponen yang akan terhubung pada ESB seperti terlihat pada arsitektur ESB pada Gambar No. 7 yang digunakan terhadap:

1. Enterprise Integration Portal

Merupakan wadah untuk mengakses aplikasi yang ada di Sekretariat Jenderal Kementerian Hukum dan HAM dan menggabungkan service-service dari beragam sumber.

2. Web Service

Memberikan sebuah perangkat standar dari konektifitas pada aplikasi / sistem lain yang membutuhkan.

3. Custom Application

Ditempelkan pada ESB untuk memberikan interface pengguna pada layanan-layanan Sistem Informasi Manajemen Sekretariat Jenderal Kementerian Hukum dan HAM, misalnya : Modul KN, Simple, dan lain-lain.

5. Data service Memberikan tampilan realtime dari data yang berasal dari sumber-sumber data yang heterogen.

6. Service Orchestration

Menaungi proses-proses bisnis yang berjalan berdasarkan standar-standar seperti Business Process Execution Language (BPEL)

7. Adapter-adapter memungkinkan integrasi dengan berbagai macam aplikasi-aplikasi eksisting dalam Sistem Informasi Manajemen Sekretariat Jenderal Kementerian Hukum dan HAM.

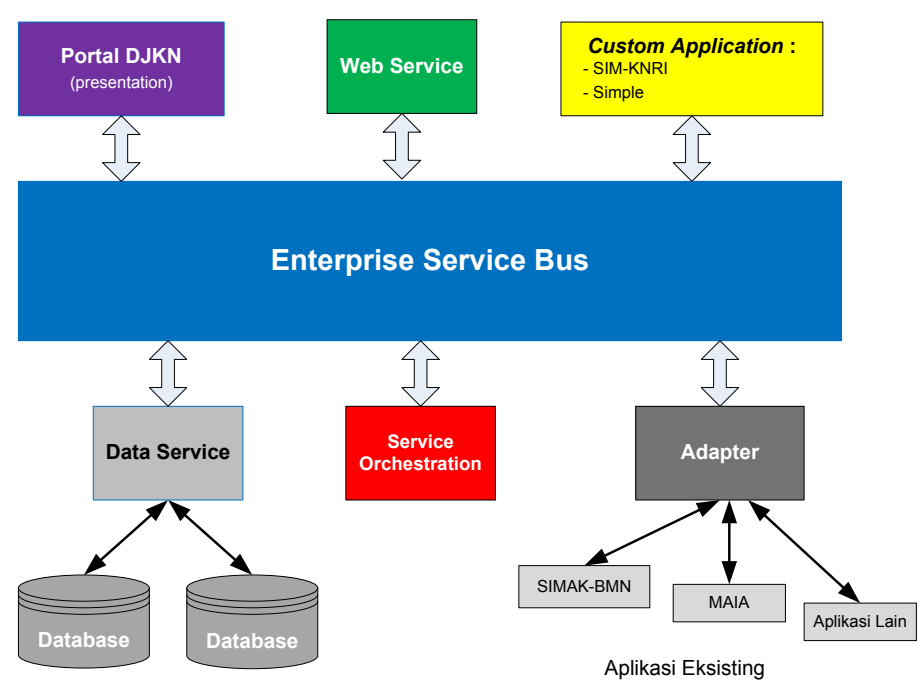

Gambar 7. Rancangan Arsitektur ESB Sistem Informasi Manajemen Sekretariat Jenderal Kementerian Hukum dan HAM berbasis SOA [8] 


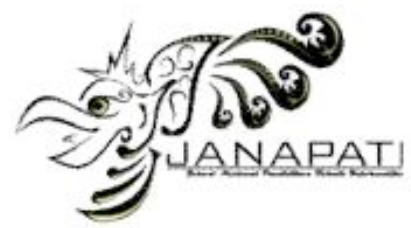

Dengan memperhatikan bahwa tidak semua aplikasi dalam lingkup Sistem Informasi Manajemen Sekretariat Jenderal Kementerian Hukum dan HAM berbasis web service yang akan diintegrasikan dalam infrastruktur SOA, software ESB yang akan digunakan harus dapat mengakomodasi aplikasiaplikasi yang tidak berbasis web service dalam mengekpos fungsi-fungsinya sebagai service-service, seperti pada rancangan, dimana fokus dari ESB adalah untuk mengintegrasikan berbagai tipe service ke dalam satu manajemen service yang terpadu.

\section{KESIMPULAN}

Kementerian Hukum dan HAM melalui Sekretariat Jenderal di Unit Pusat telah membangun pengelolaan dukungan layanan Teknologi Informasi (TI) melalui penyusunan Rencana Induk Pengembangan Sistem Informasi Manajemen Kementerian Hukum dan Hak Asasi Manusia (SIMDK) tahun 2005-2010 yang merupakan kerangka dasar pelaksanaan egovernment di lingkungan Kemeterian Hukum dan Hak Asasi Manusia. Berdasarkan Rencana Pengembangan tersebut, dihasilkan Rancangan Arsitektur Sistem Informasi Manajemen Sekretariat Jenderal Kementerian Hukum dan HAM berbasis SOA dimana konsep arsitekturnya secara umum digolongkan ke dalam 4 (empat) bagian yaitu : Aplikasi, Infrastruktur, Aliran Data dan Informasi serta Kelembagaan. Keempat bagian tersebut akan tercakup dalam rancangan Arsitektur yang terdiri dari layanan-layanan seperti berikut:

1. Layanan Pemantauan, Optimasi dan Inovasi Bisnis

2. Layanan Pengembangan Sistem Informasi dan Infrastruktur

3. Layanan Aplikasi Bisnis

4. Layanan Otomasi, Interaksi dan Kolaborasi Proses Bisnis

5. Layanan Jembatan Antar (Enterprise Service Bus)

6. Layanan Sistem Manajemen Tata Kelola TI

7. Layanan Akses Data dan Informasi

8. Layanan Aplikasi Bisnis Eksternal

9. Layanan Infrastruktur

Dalam rancangan Arsitektur tersebut Business Process Management (BPM) pada Layanan Otomasi, Interaksi dan Kolaborasi Proses Bisnis adalah infrastruktur bisnis dari SOA yang memainkan peran sentral dalam mengintegrasikan prosesproses bisnis yang terkandung di dalam organisasi. Sedangkan Layanan Jembatan Antar atau Enterprise Service Bus (ESB) adalah tahapan final dalam mengimplementasikan SOA dimana ESB mengintegrasikan layanan-layanan pada rancangan Arsitektur Sistem Informasi Manajemen Sekretariat Jenderal Kementerian Hukum dan HAM. Adapun keuntungan utama yang dapat diperoleh dengan penerapan ESB dalam Rancangan Arsitektur Sistem Informasi Manajemen Sekretariat
ISSN 2089-8673

Jurnal Nasional Pendidikan Teknik Informatika (JANAPATI)

Volume 2, Nomor 3, Desember 2013
Jenderal Kementerian Hukum dan HAM berbasis SOA antara lain :

- Akomodasi yang cepat dan relatif lebih murah terhadap sistem-sistem yang ada;

- Fleksibilitas yang tinggi, mudah beradaptasi sesuai perubahan kebutuhan;

- Berbasis standar industri TIK (best practice);

- Berskala mulai dari solusi tunggal hingga enterprise;

- Menyediakan tipe-tipe layanan yang siap digunakan yang telah didefinisikan sebelumnya;

- Lebih cenderung pada konfigurasi dibandingkan pengkodean program;

- Perubahan inkremental dapat diterapkan dengan cepat;

Untuk selanjutnya setelah dilaksanakan implementasi dari Rancangan Arsitektur Sistem Informasi Manajemen Kementerian Hukum dan Hak Asasi Manusia yang berbasis SOA yang telah dibahas dalam paper ini, perlu dilaksanakan evaluasi dan melakukan pemeriksaan (audit TI) sehingga didapat bukti-bukti yang akan menentukan apakah sistem dan teknologi informasi yang diimplementasi dapat melindungi aset organisasi, menjamin terus terjaganya integritas data, serta dapat terus beroperasi secara efektif untuk mencapai tujuantujuan organisasi.

\section{REFERENSI}

[1] Misra, H. "Understanding SOA Perspective of e-Governance in Indian Context: Case Based Study", 22 nd Bled eConference eEnablement: Facilitating an Open, Effective and Representative eSociety, June 14 17, 2009. Bled, Slovenia.

[2] Behara, G.K., Varre, V.V, and Rao, M. "Service Oriented Architecture for E-Governance", BPTrends, October, 2009.

[3] Nirmala Sugirtha Rajini, S, Bhuvaneswari, T. "Mapping Service Oriented Architecture and E-Governance", International Conference on EGovernance \& Cloud Computing Sevices, Proceedings published by International Journal of Computer Applications (IJCA), 2012.

[4] Zakaria I. Saleh, Rand A. Obeidat, Yaser Khamayseh,"A Framework for an E-government Based on Service Oriented Architecture for Jordan", IJIEEB, vol.5, no.3, pp.1-10, 2013. DOI: 10.5815/ijieeb.2013.03.01.

[5] Papazoglou, M., Traverso, P., Dustdar, S., Leymann, F., Krämer, B. "Service-Oriented Computing Research Roadmap", International Journal of Cooperative Information Systems (IJCIS), 2008.

[6] Sellami, M., Jmaiel, M. "A Secured Service-Oriented Architecture for E-government in Tunisia", ReDCAD research unit National School of Engineers of Sfax, 2011.

[7] Peraturan Menteri Hukum Dan Hak Asasi Manusia Nomor : M.HH01.PR.01.01 Tahun 2010 Tentang Rencana Strategis Kementerian Hukum Dan Hak Asasi Manusia Tahun 2010-2014.

[8] Dokumen IT Master Plan Kementerian Hukum dan Hak Asasi Manusia RI Tahun 2010-2015. 